\title{
PENGARUH KOMPENSASI DAN LINGKUNGAN KERJA TERHADAP KINERJA KARYAWAN
}

\author{
Vivi Herlina \\ STIA NUSA Sungai Penuh \\ Email: viviherlina124@gmail.com
}

\begin{abstract}
Abstrak
Kinerja karyawan sangat penting bagi kemajuan sebuah perusahaan. Oleh karena itu, penelitian ini dilakukan untuk mengetahui pengaruh kompensasi dan lingkungan kerja terhadap kinerja karyawan dengan mengambil studi kasus pada PT. Perkebunan Nusantara VI (Persero) Kayu Aro. Penelitian dilakukan untuk mencari besar pengaruh baik secara simultan maupun secara parsial, serta variabel yang paling dominan mempengaruhi kinerja karyawan. Metode yang digunakan adalah analisis regresi linier. Diketahui bahwa besar pengaruh Kompensasi terhadap Kinerja Karyawan adalah 0,1512. Kemudian besar pengaruh Lingkungan Kerja terhadap Kinerja Karyawan sebesar 0,1008. Sementara hasil analisis variabel independen Kompensasi dan Lingkungan Kerja secara simultan terhadap Kinerja Karyawan diperoleh $R$ Square sebesar 0.0500, berarti bahwa besar pengaruh antara Kompensasi dan Lingkungan Kerja terhadap Kinerja Karyawan adalah sebesar 0,50\%. Berdasarkan hasil analisis variabel independen diketahui nilai Kompensasi 0,1512\% dan Lingkungan Kerja sebesar 0,1008\%, maka variabel yang paling dominan berpengaruh terhadap Kinerja Karyawan adalah Kompensasi dengan nilai 0,1512\%.
\end{abstract}

Kata Kunci: Kompensasi; Lingkungan Kerja; Kinerja Karyawan; Regresi Linier; $R$ Square

\begin{abstract}
Employee performance is very important for the progress of a company. Therefore, this study was conducted to determine the effect of compensation and work environment on employee performance by taking case studies at PT. Perkebunan Nusantara VI (Persero) Kayu Aro. The study was conducted to find the influence of both simultaneously and partially, and the most dominant variables affect employee performance. The principal method that using in this study is linear regression analysis. The influence of Compensation on Employee Performance is 0.1512 and the influence of the Work Environment on Employee Performance is 0.1008. The results of independent variables analysis between Compensation and Work Environment simultaneously on Employee Performance obtained $R$ Square is 0.0500. It means that the magnitude of the influence between Compensation and Work Environment on Employee Performance is equal to 0.50\%. Based on the results of the independent variable analysis that the Compensation value is $0.1512 \%$ and the Work Environment is $0.1008 \%$, so the most dominant variable influencing Employee Performance is Compensation.
\end{abstract}

Keywords: Compensation; Performance: Work Environment; Linear Regression; $R$ Square 


\section{PENDAHULUAN}

Sejalan dengan persaingan yang ketat disebabkan perubahan teknologi dan perubahan lingkungan dalam semua bidang kehidupan maka semua perusahaan mencari karyawan yang memiliki potensi guna memberi pelayanan terbaik serta bermanfaat. Dengan begitu perusahaan tidak hanya memberikan pelayanan yang memuaskan (customer satisfaction) tetapi juga berorientasi pada nilai (customer value). Perusahaan dalam menjalankan operasional tidak hanya mengejar produktivitas tetapi lebih pada kinerjanya.

Kinerja karyawan merupakan salah satu faktor yang penting karena kemajuan organisasi atau perusahaan tergantung dari sumber daya manusia yang dimiliki. Jika kinerja meningkat maka keberhasilan mencapai tujuan perusahaan semakin terbuka lebar, tetapi apabila kinerja menurun maka bisa mengakibatkan kemunduran bagi perusahaan dan perusahaan tidak dapat mempertahankan usahanya.

Kinerja karyawan ada kalanya mengalami peningkatan dan ada kalanya mengalami penurunan, bahkan penurunan tersebut dapat mencapai titik yang dapat mengakibatkan institusi atau perusahaan akan kehilangan pamornya di mata masyarakat. Hal ini perlu diperhatikan dan dipelajari bersama apa yang harus dilakukan untuk mengantisipasi hal tersebut.

Penelitian terdahulu sangat penting sebagai dasar pijakan dalam rangka penyusunan penelitian ini. Salah satu kegunaannya berguna untuk mengetahui hasil yang telah dilakukan oleh peneliti terdahulu. Dwi Septianto melakukan penelitian dengan judul Pengaruh Lingkungan Kerja dan Stres Kerja Terhadap Kinerja Karyawan, Studi Pada PT. Pataya Raya Semarang. Berdasarkan hasil penelitiannya yang telah dianalisis dan pembahasan yang diuraikan dapat disimpulkan bahwa lingkungan kerja pada PT. Pataya Raya Semarang mempunyai pengaruh positif signifikan terhadap kinerja karyawan ditolak. Karena dari hasil penelitian diperoleh nilai signifikan lebih besar dari 0,05 yaitu sebesar 0,102. Sedangkan stres kerja pada PT. Pataya Raya Semarang mempunyai pengaruh negatif signifikan terhadap kinerja karyawan ditolak. Karena dari hasil penelitian diperoleh nilai signifikan lebih besar dari 0,05 yaitu sebesar 0,173. Dan berdasarkan nilai Adjusted $R$ Square dapat diketahui pengaruh lingkungan kerja dan stres kerja terhadap kinerja karyawan bagian karyawan operasional pada PT. Pataya Raya Semarang sebesar 4,5\% (Septianto, 2010).

Selanjutnya penelitian oleh Lynawati dengan judul: Pengaruh Kompensasi, Stres Kerja, dan Komunikasi Terhadap Kinerja Karyawan PT Bank Rakyat Indonesia Cabang Puwokerto, menjelaskan bahwa kompensasi, stres kerja, dan komunikasi secara parsial maupun simultan mempunyai pengaruh signifikan terhadap kinerja karyawan. Hal tersebut dibuktikan dengan nilai hasil uji $\mathrm{t}$ dan uji $\mathrm{F}$ yang lebih besar daripada nilai $\mathrm{t}$ tabel dan $\mathrm{F}$ tabel pada taraf kepercayaan 95\%. Selanjutnya, kompensasi mempunyai pengaruh paling besar terhadap kinerja karyawan dibandingkan stres kerja dan komunikasi. Hal tersebut dibuktikan dengan pengaruh proporsional variabel kompensasi yang lebih besar dibandingkan pengaruh proporsional variabel stres kerja dan komunikasi. Dari perhitungan analisis jalur diketahui bahwa pengaruh proporsional variabel Kompensasi (X1) sebesar 0,4320 (43,20\%), pengaruh proporsional variabel Stres kerja (X2) sebesar 0,2005 (20,05\%), dan pengaruh proporsional variabel Komunikasi (X3) sebesar 0,1405 (14,05\%). Jadi, pengaruh proporsional yang terbesar adalah pada variabel Kompensasi (X1) yang berarti kompensasi merupakan variabel yang mempunyai pengaruh paling besar. Dengan demikian kinerja karyawan (Y) dari hasil penelitian melalui pengujian statistik menunjukkan bahwa kompensasi, stres kerja dan komunikasi berpengaruh signifikan terhadap kinerja karyawan (Lynawati, 2016).

Penelitian terdahulu lainnya, dilakukan oleh Aan Hardiyana, dan Adhie Fasha Nurhadian dengan judul penelitian "Pengaruh Kompensasi dan Motivasi Kerja Terhadap 
Kepuasan Kerja Serta Implikasinya pada Kinerja Karyawan" menjelaskan bahwa kompensasi berpengaruh signifikan terhadap kepuasan kerja karyawan. Kompensasi memberikan pengaruh yang paling dominan terhadap kepuasan kerja karyawan. Hasil tersebut menunjukkan terdapat pengaruh cukup signifikan dimana kompensasi sangat penting untuk meningkatkan kepuasan kerja karyawan. Dari hasil penelitian diperoleh bahwa secara simultan terdapat pengaruh signifikan kompensasi dan motivasi terhadap kepuasan kerja karyawan. Kontribusi kompensasi dan motivasi terhadap kepuasan kerja sebesar 60,1\% sedangkan sebesar 39,9\% dipengaruhi faktor lain (Hardiyana and Fasha Nurhadian, 2016).

Dari penelitian terdahulu tersebut, peneliti mencoba melakukan penelitian mengenai Pengaruh Kompensasi dan Lingkungan Kerja Terhadap Kinerja Karyawan pada PT. Perkebunan Nusantara VI (Persero) Kayu Aro di Kab. Kerinci dengan menggunakan analisis regresi.

\section{TINJAUAN LITERATUR}

Kompensasi adalah segala sesuatu yang diterima para karyawan sebagai balas jasa untuk kerja mereka (Handoko, 2008, p. 218). Menurut Hasibuan (2007, p. 117), kompensasi diartikan sebagai semua pendapatan yang berbentuk uang, barang langsung atau tidak langsung yang diterima karyawan sebagai imbalan atas jasa yang diberikan kepada perusahaan.

Berdasarkan beberapa teori tersebut dapat disimpulkan kompensasi merupakan pemberian penghargaan baik finansial maupun non finansial yang diterima oleh pegawai sebagai imbalan atas jasanya yang diberikan kepada organisasi, dan juga digunakan sebagai motivator atau perangsang oleh organisasi dalam meningkatkan prestasi kerja.

Tanpa adanya kompensasi, kebutuhan-kebutuhan lanjutan tidak dapat berfungsi sesuai dengan kaidah Maslow bahwa kebutuhan yang lebih tinggi hanya dapat berfungsi jika kebutuhan yang lebih rendah telah terpenuhi. Sistem kom- pensasi tidak hanya memuaskan kebutuhan fisik melainkan juga merupakan pengakuan dan rasa mencapai sesuatu.

Menurut Netisemito (2000, p. 183) lingkungan kerja adalah sesuatu yang ada di sekitar pekerja dan yang dapat mempengaruhi dirinya dalam menjalankan tugas-tugas yang dibebankan. Sedangkan menurut Wursanto (2009, p. 287), lingkungan kerja dibedakan menjadi dua macam yaitu, kondisi lingkungan kerja yang menyangkut segi fisik dan kondisi lingkungan kerja yang menyangkut segi non fisik. Kondisi lingkungan kerja yang menyangkut segi fisik adalah segala sesuatu yang menyangkut segi fisik dari lingkungan kerja. Sedangkan lingkungan kerja segi non fisik merupakan lingkungan kerja yang tidak dapat ditangkap dengan panca indera, seperti warna, bau, suara dan rasa.

Prawirosentono dalam Sinambela, dkk (2006, p. 137) menjelaskan kinerja adalah hasil kerja yang dapat dicapai oleh pegawai atau sekelompok pegawai dalam suatu organisasi, sesuai dengan wewenang dan tanggung jawab masing-masing, dalam upaya mencapai tujuan organisasi bersangkutan secara legal, tidak melanggar hukum dan sesuai dengan moral dan etika. Harbani Pasolong (2007, p. 175) mengatakan kinerja pegawai adalah hasil kerja perseorangan dalam suatu organisasi. Selanjutnya Withmore dalam Sinambela, dkk (2006, p. 138) mengemukakan kinerja merupakan ekspresi potensi seseorang dalam memenuhi tanggungjawabnya dengan menetapkan standar tertentu.

Menurut Anwar Prabu Mangkunegara (2006, p. 67) dalam bukunya Manajemen Sumber Daya Manusia Perusahaan, mengemukakan pengertian kinerja adalah hasil kerja secara kualitas dan kuantitas yang dicapai oleh seorang karyawan dalam melaksanakan tugasnya sesuai dengan tanggung jawab yang diberikan padanya.

Selanjutnya peneliti juga akan mengemukakan tentang definisi kinerja karyawan menurut Bernandin \& Russell (1995, p. 135) yang dikutip oleh Faustino Cardoso Gomes dalam bukunya 
yang berjudul Human Resource Management, Performansi adalah catatan yang dihasilkan dari fungsi suatu pekerjaan tertentu atau kegiatan selama periode waktu tertentu. Menurut Wibowo (2011, p. 25) mengemukakan bahwa kinerja bersal dari pengertian performance. Menurut Hasibuan (2007, p. 52) menguraikan bahwa kinerja adalah suatu hasil kerja yang dicapai seseorang dalam melaksanakan tugas-tugas yang dibebankan kepadanya yang didasarkan atas kecakapan, pengalaman dan kesungguhan serta waktu. Mangku Negara (2006, p. 67) menjelaskan kinerja adalah hasil kerja yang secara kualitas dan kuantitas yang dicapai oleh seorang pegawai dalam melaksanakan tugasnya sesuai dengan tanggung jawab yang diberikan kepadanya. Sedangkan menurut Sidermayanti (2001, p. 34) kinerja berarti setiap kesediaan perasaan yang memungkinkan seseorang bekerja untuk menghasilkan kerja lebih banyak dan lebih baik tanpa menambah kelebihan.

Berdasarkan uraian tersebut di atas mengungkapkan bahwa dengan hasil kerja yang dicapai oleh seorang karyawan dalam melakukan suatu pekerjaan dapat dievaluasi tingkat kinerja pegawainya, maka kinerja karyawan harus dapat ditentukan dengan pencapaian target selama periode waktu yang dicapai organisasi.

Menurut Bangun (2012, p. 230) menyatakan kinerja adalah hasil pekerjaan yang dicapai seseorang berdasarkan persyaratan-persyaratan pekerjaan. Sedangkan menurut Rivai dan Sagala (2009, p. 548) kinerja adalah perilaku yang diperlihatkan oleh semua individu sebagai prestasi kerja yang dihasilkan oleh karyawan. Menurut Bangun (2012, p. 232), bagi suatu perusahaan penilaian kinerja memiliki berbagai manfaat antara lain, evaluasi antar individu dalam organisasi, pengembangan diri setiap individu, pemeliharaan sistem, dan dokumentasi.

Kinerja/produktivitas sumberdaya manusia juga dapat dipengaruhi oleh banyak faktor diantaranya kompensasi, lingkungan kerja, kepuasan kerja, dan motivasi. Salah satu yang menjadi pertimbangan kinerja karyawan adalah kompensasi yang adil dan lingkungan kerja yang sesuai. Menurut Bangun (2012, p. 254), kompensasi merupakan salah satu faktor penting dan menjadi perhatian pada banyak organisasi dalam mempertahankan dan menarik sumberdaya manusia yang berkualitas. Menurut Fajar dan Heru (2010, p. 154) kompensasi adalah seluruh extrinsic rewards yang didapat karyawan dalam bentuk upah, insentif, dan beberapa tunjangan (benefits).

Menurut Fajar dan Heru (2010, p. 155) kompensasi mempunyai beberapa tujuan utama:

1) Menarik pelamar kerja yang potensial

2) Mempertahankan karyawan yang baik

3) Meraih keunggulan kompetitif

4) Meningkatkan produktivitas

5) Melakukan pembayaran yang sesuai dengan aturan hukum (Undang-Undang Ketenagakerjaan).

6) Menjamin keadilan

7) Memudahkan sasaran strategi

Menurut Nitisemito dalam (Sariyathi 2000, p. 66) lingkungan kerja merupakan semua yang ada pada lingkungan pekerja yang mampu mempengaruhi diri dalam menjalankan pekerjaannya. Lingkungan kerja dalam organisasi mempunyai pengaruh penting untuk kelancaran produksi dengan lingkungan yang sesuai, sehingga mampu memuaskan karyawan dalam melaksanakan kegiatan, tapi juga dapat berpengaruh terhadap peningkatan kinerja.

Manusia dapat melaksanakan pekerjaannya dengan baik, apabila ditunjang oleh kondisi lingkungan yang sesuai. Suatu kondisi lingkungan dikatakan baik atau sesuai apabila manusia dalam melaksanakan kegiatannya merasa aman dan nyaman. Ketidaksesuaian lingkungan kerja dapat menimbulkan akibat dalam jangka panjang. 
Sumber daya manusia adalah modal awal yang dimiliki oleh perusahaan yang memegang peranan penting dalam keberhasilan untuk menjadikan PT. Perkebunan Nusantara VI (Persero) Kayu Aro sebagai lembaga penyokong ekonomi Kabupaten Kerinci. Dengan adanya karyawan tersebut diharapkan kegiatan perusahaan dapat terlaksana dengan baik. Oleh karena itu, kinerja karyawan dituntut untuk lebih profesional guna meraih prestasi dalam bekerjanya dan mencapai tujuan perusahaan.

PT. Perkebunan Nusantara VI (Persero) Kayu Aro, dalam aktivitas bekerjanya selalu menekankan kepada seluruh sumber daya manusianya untuk mencapai kinerja yang baik. PT. Perkebunan VI (Persero) Kayu Aro adalah Badan Usaha Milik Negara yang bergerak di bidang Perkebunan Teh.

Penilaian kinerja merupakan suatu proses organisasi dalam melalui untuk kerja pegawainya. Tujuan dilakukan penilaiaan kinerja secara umum adalah untuk memberikan feedback kepada pegawai dalam upaya memperbaiki tampilan kerjanya dan upaya meningkatkan kinerja organisasi.

Fenomena yang terjadi pada pada karyawan PT. Perkebunan Nusantara VI (Persero) Kayu Aro yang menurut pengamatan penulis adalah sebagai berikut:

1. Kurangnya bentuk kompensasi yang diinginkan karyawan, dan manajemen memberikan tugas yang terlalu mudah atau terlalu sulit sehingga karyawan kurang termotivasi.

2. Lingkungan kerja yang dirasa kurang nyaman bagi karyawan diantaranya, cahaya yang kurang terang di tempat kerja sehingga karyawan mengalami kesulitan dalam bekerja yang mengakibatkan tingkat resiko kecelekaan tinggi disertai pula dengan temperatur udara di ruangan kerja yang cukup panas.

3. Pencapaian kinerja karyawan dapat dikatakan belum optimal dan cenderung menurun. Jika terjadi penurunan kinerja karyawan setiap tahunnya maka akan berdampak negatif bagi perusahaan, karena dapat menghambat produktivitas perusahaan. Indikasi permasalahan di lapangan terletak pada kepuasan kompensasi yang dirasa kurang terutama masalah gaji dan juga hubungan sesama rekan kerja atau teman kerja masih sering terdapat hubungan yang kurang harmonis.

Berdasarkan pemaparan tersebut dapat dijadikan permasalahan penelitian mengenai "Pengaruh Kompensasi Dan Lingkungan Kerja terhadap Kinerja Karyawan," dengan studi kasus pada PT. Perkebunan Nusantara VI (Persero) Kayu Aro-Kab. Kerinci.

Berdasarkan uraian di atas, adapun tujuan dari penelitian ini adalah sebagai berikut untuk mengetahui pengaruh kompensasi dan lingkungan kerja terhadap kinerja karyawan baik secara parsial maupun secara simultan serta untuk mengetahui variabel yang paling dominan mempengaruhi kinerja karyawan pada PT. Perkebunan Nusantara VI (Persero) Kayu Aro.

\section{METODE PENELITIAN}

Metode pendekatan penelitian yang digunakan dalam penelitian ini adalah metode deskriptif kuantitatif. Metode deskriptif kuantitatif merupakan alat untuk menganalisis dengan melakukan perhitungan tingkat pengaruh Kompensasi dan Lingkungan Kerja terhadap Kinerja karyawan PT. Perkebunan Nusantara VI (Persero) Kayu Aro dengan menggunakan teknik analisis linier.

Adapun hipotesa yang digunakan dalam penelitian ini yaitu:

Ho : $\mathbf{r} \neq \mathbf{0}$ :

Tidak Terdapat Pengaruh Kompensasi dan Lingkungan kerja Terhadap Kinerja Karyawan PT. Perkebunan Nusantara VI (Persero) Kayu Aro.

Ho : $\mathbf{r}=\mathbf{0}$ : 
Terdapat Pengaruh Kompensasi dan Lingkungan kerja Terhadap Kinerja Karyawan PT. Perkebunan Nusantara VI (Persero) Kayu Aro.

Dalam penelitian ini terdapat variabel penelitian yaitu:

\section{Variabel Bebas (Independent Variable) (X. 1 dan X.2)}

a) Kompensasi adalah semua bentuk pemberian balas jasa pada pekerja (karyawan), baik yang langsung berupa uang (finansial) maupun tidak langsung berupa non uang (non finansial).

Indikator Kompensasi adalah:

1. Kompensasi Langsung
a. Gaji
b. Upah
c. Insentif/Bonus

2. Kompensasi Tdk Langsung
a. Tunjangan Keuangan
b. Tunjangan Hari raya
c. Kesejahteraan Karyawan / jamsostek

b) Lingkungan kerja adalah segala sesuatu yang ada di sekitar para pekerja (karyawan) yang dapat mempengaruhi dirinya dalam menjalankan tugas yang diemban. Indikator Lingkungan kerja adalah:

1. Penerangan cahaya

2. Suhu Udara

3. Suara Bising

4. Dekorasi/Tata Ruang

5. Hubungan Karyawan

\section{Variabel Dependent (Variabel Y)}

Kinerja adalah hasil kerja yang dapat dicapai oleh seseorang atau dari kelompok orang dalam suatu organisasi, sesuai dengan wewenang dan tanggung jawab masing-masing dalam rangka upaya mencapai tujuan organisasi bersangkutan secara legal, tidak melanggar hukum dan sesuai dengan norma maupun etika.

Indikator Kinerja Karyawan adalah sebagai berikut:

1. Memiliki tanggung jawab pribadi

2. Berani mengambil dan menangggung resiko

3. Memiliki tujuan yang realistis

4. Memiliki rencana kerja

5. Memanfaatkan umpan balik

Dalam penelitian ini penulis menggunakan analisis statistik regresi linier sederhana, persamaan yang digunakan adalah $\mathbf{Y}=\mathbf{a}+\mathbf{b} \mathbf{X}+\mathbf{e}$

Dimana:

$\mathrm{X}=$ Kompensasi dan Lingkungan Kerja

$\mathrm{Y}=$ Kinerja Karyawan

a $=$ Konstanta

$\mathrm{b}=$ Koefisien regresi

e $=$ Error / variabel pengganggu

Sugiono (2003, p. 123) menyebutkan bahwa analisis regresi linear berganda adalah Suatu alat analisis peramalan nilai pengaruh dua variabel bebas atau lebih terhadap variabel 
terikat untuk membuktikan ada atau tidaknya pengaruh fungsi atau pengaruh kausal antara dua variabel bebas atau lebih dengan satu variabel terikat. Dalam penelitian ini teknik analisa data yang digunakan adalah Regresi Liner berganda dengan penyelesaian menggunakan SPSS versi 17. Model persamaan untuk analisa regresi berganda adalah $Y=\boldsymbol{\alpha}+\boldsymbol{\beta}_{1} \mathbf{X}_{1}+\boldsymbol{\beta}_{2} \mathbf{X}_{2}+\mathbf{e}$.

Dimana

$\begin{array}{ll}\mathrm{Y} & : \text { Kinerja Karyawan } \\ \alpha & : \text { Konstanta } \\ \mathrm{X} 1 & : \text { Kompensasi } \\ \mathrm{X} 2 & : \text { Lingkungan Kerja } \\ \beta 1 & : \text { Koefisien Regresi X1 } \\ \beta 22 & : \text { Koefisien Regresi X2 } \\ \mathrm{e} & : \text { Error }\end{array}$

Selanjutnya untuk menguji hipotesis yang diajukan maka dilakukan pengujian dengan Uji t ( t test) dengan alpha 5\%. Berikutnya dilakukan perhitungan koefisien Determinasi $\left(\mathrm{R}^{2}\right)$ untuk mengukur seberapa besar kontribusi variabel bebas $(\mathrm{X})$ terhadap variabel terikat $(\mathrm{Y})$. Teknik ini digunakan untuk mengetahui berapa persen besarnya pengaruh variabel bebas terhadap variabel terikat. Kemudian dilakukan Uji F untuk mengetahui pengaruh variabel Kompensasi dan Lingkungan Kerja secara bersama-sama terhadap Kinerja Karyawan PT. (Persero) Perkebunan VI Kayu Aro.

\section{HASIL DAN DISKUSI}

Berdasarkan data dari jawaban responden yang diperoleh di lokasi penelitian. Peneliti melakukan pengolahan data yang sekaligus menjadi pembahasan dalam penelitian ini.

\section{Pengaruh Kompensasi dan Lingkungan Kerja terhadap Kinerja Karyawan}

Untuk mengetahui atau menguji ada tidaknya Pengaruh Kompensasi dan Lingkungan Kerja secara Simultan Terhadap Kinerja Karyawan PT. Perkebunan Nusantara VI (Persero) Kayu Aro, dapat dilihat pada tabel 1 di bawah ini:

Tabel 1. Coefficients ${ }^{\mathrm{a}}$

\begin{tabular}{|c|c|c|c|c|c|c|c|c|c|c|c|c|c|}
\hline & \multirow[b]{2}{*}{ Model } & \multicolumn{2}{|c|}{$\begin{array}{l}\text { Unstandardized } \\
\text { Coefficients }\end{array}$} & \multirow{2}{*}{$\begin{array}{c}\text { Standardized } \\
\text { Coefficients } \\
\text { Beta }\end{array}$} & \multirow[b]{2}{*}{$\mathrm{t}$} & \multirow[b]{2}{*}{ Sig. } & \multicolumn{2}{|c|}{$\begin{array}{l}\text { 95\% Confidence } \\
\text { Interval for B }\end{array}$} & \multicolumn{3}{|c|}{ Correlations } & \multicolumn{2}{|c|}{$\begin{array}{l}\text { Collinearity } \\
\text { Statistics }\end{array}$} \\
\hline & & B & Std. Error & & & & $\begin{array}{l}\text { Lower } \\
\text { Bound }\end{array}$ & $\begin{array}{l}\text { Upper } \\
\text { Bound }\end{array}$ & $\begin{array}{l}\text { Zero- } \\
\text { order }\end{array}$ & Partial & Part & $\begin{array}{l}\text { Tole } \\
\text { rance }\end{array}$ & VIF \\
\hline 1 & (Constant) & 13.170 & 7.934 & & 1.660 & .116 & -3.649 & 29.989 & & & & & \\
\hline & Kompensasi & .336 & .222 & .446 & 1.512 & .150 & -.135 & .808 & .684 & .354 & .267 & .359 & 2.787 \\
\hline & L.Kerja & .135 & .134 & .298 & 1.008 & .328 & -.149 & .419 & .655 & .244 & .178 & .359 & 2.787 \\
\hline
\end{tabular}

Berdasarkan Tabel 1: Coefficients di atas, diketahui persamaan Regresi berganda sebagai berikut:

$\mathrm{Y}=\mathrm{a}+\mathrm{b}_{1} \mathrm{X}_{1}+\mathrm{b}_{2} \mathrm{X}_{2}$

Maka $Y=13,170+0,336 X_{1}+0,135 X_{2}$ 
Adapun maksud dari persamaan di atas adalah apabila dianggap tidak ada Kompensasi dan Lingkungan Kerja atau $=0$, maka Kinerja Karyawan PT. Perkebunan Nusantara VI (Persero) Kayu Aro adalah sebesar 13,170.

Nilai $b_{1}=0,336$ menunjukkan apabila nilai Kompensasi dinaikkan $100 \%$ maka Kinerja Karyawan PT. Perkebunan Nusantara VI (Persero) Kayu Aro akan mengalami kenaikan sebesar sebesar 3,36. Sedangkan nilai $b_{2}=0,135$, yang artinya apabila nilai Lingkungan Kerja dinaikkan 100\% maka Kinerja Karyawan PT. Perkebunan Nusantara VI (Persero) akan mengalami kenaikan sebesar 1,35.

\begin{tabular}{|c|c|c|c|c|c|c|c|}
\hline \multicolumn{7}{|l|}{ Besar Pengaruh } & \multirow{7}{*}{$\begin{array}{l}\text { Kompensasi } \\
\text { Secara Simultan } \\
\text { Karyawan } \\
\text { didapatkan nilai R } \\
\text { yang berarti bahwa } \\
\text { Kompensasi } \\
\text { terhadap dan } \\
\text { Perkebunan Nusantara } \\
\text { sebesar 50\%. } \\
\text { mengetahui }\end{array}$} \\
\hline \multirow{2}{*}{$\begin{array}{c}\text { Lingkungan } \\
\text { Kerja } \\
\text { Serhadap } \\
\text { Kinerjatnya }\end{array}$} & \multicolumn{6}{|c|}{ Tabel 2. ANOVA ${ }^{b}$} & \\
\hline & Model & $\begin{array}{l}\text { Sum of } \\
\text { Squares }\end{array}$ & df & $\begin{array}{l}\text { Mean } \\
\text { Square }\end{array}$ & $\mathrm{F}$ & Sig. & \\
\hline \multirow{4}{*}{$\begin{array}{l}\text { Square sebesar } \\
\text { besar per } \\
\text { Lingkungan } \\
\text { Karyawan } \\
\text { VI (Persero) Ka }\end{array}$} & $\begin{array}{c}1 \text { Regressio } \\
\mathrm{n}\end{array}$ & 117.964 & & 58.982 & 8.009 & $.004^{a}$ & \\
\hline & Residual & 117.825 & 16 & 7.364 & & & \\
\hline & Total & 235.789 & 18 & & & & \\
\hline & $\begin{array}{l}\text { a. Predictors } \\
\text { b. Depender }\end{array}$ & $\begin{array}{l}\text { : (Constar } \\
\text { t Variable }\end{array}$ & & $\begin{array}{l}\text { Kerja, } \\
\text { erja }\end{array}$ & & & \\
\hline
\end{tabular}

menguji hipotesis Pengaruh Kompensasi dan Lingkungan Kerja secara Simultan terhadap Kinerja Karyawan PT Perkebunan Nusantara VI (Persero) Kayu Aro maka dapat digunakan alat uji statistik $\mathrm{F}$ dengan analisis pada tabel di bawah ini:

Berdasarkan tabel anova di atas diketahui nilai uji F adalah 8.009, (Sig. = 0,004, maka Ha diterima Ho ditolak, berarti Kompensasi dan Lingkungan Kerja secara Simultan berpengaruh tidak signifikan terhadap Kinerja karyawan PT. Perkebunan Nusantara VI (Persero) Kayu Aro.

Untuk menguji ada tidaknya Pengruh Kompensasi Terhadap Kinerja Karyawan PT. Perkebunan Nusantara VI (Persero) Kayu Aro, maka digunakan alat uji Statistik T. Kompensasi nilai thitung sebesar 1,512 (Sig. $=0,150)$, artinya Ha diterima Ho ditolak, artinya Kompensasi berpengaruh tidak signifikan terhadap Kinerja Karyawan PT. Perkebunan Nusantara VI (Persero) Kayu Aro. Untuk mengetahui atau menguji ada tidaknya Pengaruh Lingkungan Kerja Terhadap Kinerja Karyawan PT. Perkebunan Nusantara VI (Persero) Kayu Aro, dimana nilai T hitung 1,008 (Sig. $=0,328)$, artinya Ha diterima. Sedangkan Ho ditolak, artinya Lingkungan Kerja berpengaruh tidak Signifikan terhadap Kinerja Karyawan PT. Perkebunan Nusantara VI (Persero) Kayu Aro). 


\section{SIMPULAN} berikut:

Dari hasil penelitian secara kuantitatif dalam penelitian ini dapat disimpulkan sebagai

1. Berdasarkan hasil analisis variabel Independen bahwa Kompensasi berpengaruh terhadap Kinerja Karyawan, merujuk pada hasil uji t hitung sebesar 1.5.12 (Sig. = 0,150), dengan demikian Ha diterima, dan Ho ditolak. Kemudian hasil analisis diperoleh kecenderungan bahwa Lingkungan Kerja berpengaruh terhadap Kinerja Karyawan. Merujuk pada hasil yang didapatkan pengaruhnya sebesar 0,500. Dengan demikian hipotesis kedua dapat diterima, artinya terdapat pengaruh yang signifikan antara Lingkungan Kerja dengan Kinerja Karyawan. Sementara hasil analisis variabel independen Kompensasi dan Lingkungan Kerja terhadap Kinerja Karyawan, dimana uji F adalah 8.009, (Sig. = 0,004), maka Ha diterima Ho ditolak, berarti Kompensasi dan Lingkungan Kerja secara Simultan berpengaruh secara signifikan terhadap Kinerja karyawan PT. Perkebunan Nusantara VI (Persero) Kayu Aro.

2. Diketahui bahwa besar pengaruh Kompensasi terhadap Kinerja Karyawan adalah 0,1512. Kemudian besar pengaruh Lingkungan Kerja terhadap Kinerja Karyawan, sebesar 0,1008. Sementara hasil analisis variabel independen Kompensasi dan Lingkungan Kerja secara simultan terhadap Kinerja Karyawan diperoleh R Square sebesar 0.0500, berarti bahwa besar pengaruh antara Kompensasi dan Lingkungan Kerja terhadap Kinerja Karyawan adalah sebesar $0,050 \%$.

3. Berdasarkan hasil analisis variabel independen diketahui nilai Kompensasi 0,1512\% dan Lingkungan Kerja sebesar 0,1008 \%, maka variabel yang paling dominan berpengaruh terhadap Kinerja Karyawan adalah Kompensasi dengan nilai 0,1512\%.

\section{DAFTAR PUSTAKA}

Bangun, W. (2012) Manajemen Sumber Daya Manusia. Bandung: Erlangga.

Bernardin, J. H. and J. E. . R. (1995) Human resources management: an experiential approach. New York: McGraw-Hill Book Company, Inc.

E.J, R. V. \& S. (2009) Manajemen Sumber Daya Manusia untuk Perusahaan : Dari Teori ke Praktik. 2nd edn. Jakarta: Rajawali Press.

Al Fajar, S. dan T. H. (2010) Manajemen Sumber Daya Manusia: Sebagai Dasar Meraih Keunggulan Bersaing. Yogyakarta: YKPN.

Handoko, T. H. (2008) Manajemen Personalia dan Sumber Daya manusia. 6th edn. Yogyakarta: BPFE.

Harbani, P. (2007) Teori Administrasi Publik. Jakarta: Alfabeta.

Hardiyana, A. and Fasha Nurhadian, A. (2016) 'Pengaruh Kompensasi dan Motivasi Kerja Terhadap Kepuasan Kerja Serta Implikasinya pada Kinerja Karyawan', Jurnal Ekonomi, Bisnis \& Entrepreneurship, 10(2), pp. 104-118.

Hasibuan, M. (2007) Manajemen Sumber Daya Manusia. Jakarta: Bumi Aksara.

Lynawati (2016) 'Pengaruh Kompensasi, Stres Kerja, dan Komunikasi Terhadap Kinerja Karyawan PT Bank Rakyat Indonesia Cabang Purwokerto', Jurnal Manajemen dan Bisnis MEDIA EKONOMI, XVI(2), pp. 220-228.

Mangku Negara, A. P. (2006) Manajemen Sumber Daya Manusia Perusahaan. Bandung: Remaja Rosda Karya.

Netisemito, Alex, S. (2000) Manajemen Sumber Daya Manusia. Jakarta: Salemba Empat.

Sedarmayanti (2001) Sumber Daya Manusia dan Produktivitas Kerja. Bandung: Mandar Maju. Septianto, D. (2010) 'Pengaruh Lingkungan Kerja dan Stres Kerja Terhadap Kinerja Karyawan Studi Pada PT. Pataya Raya Semarang', Jurnal Studi Manajemen Organisasi, 12(1), pp. 
$1-5$.

Sinambela et al (2006) Reformasi Pelayanan Publik, Teori Kebijakan dan Implementasi. Jakarta: Bumi Aksara.

Sugiyono (2003) Metode Penelitian Administrasi. Bandung: Alfabeta.

Wibowo (2011) Manajemen Kinerja. Jakarta: Raja Grafindo Persada.

Wursanto (2009) Manajemen Sumber Daya Manusia. Jakarta: Salemba Empat. 